\title{
Auditors' Duty to Ensure Clients are Using Accounting Practices in Compliance with Generally Accepted Accounting Principles: A Case Study of Infinity Business Group, Inc.
}

\author{
Stephen Errol Blythe \\ Tarleton State University Fort Worth, Texas USA
}

\begin{abstract}
Infinity Business Group, Inc. (IBG), a company specializing in the collection of bad checks, was incorporated in 2003. IBG recorded its collection fees as Accounts Receivable even before the Not-Sufficient-Funds checks were collected, a method not in compliance with Generally Accepted Accounting Principles; accordingly, IBG's auditor should not have issued unqualified opinions on the financial statements during 2003-2008. A \$23 million write-off of Accounts Receivable in 2009 had a devastating effect on the company and it declared bankruptcy in 2010. In 2019, the Bankruptcy Court ruled: (a) the auditor's unqualified opinions violated the U.S. Securities Exchange Act, and the auditor was forced to plead guilty to one felony count of securities fraud; (b) IBG's CFO was dishonest when he responded to an inquiry from a lender about the Accounts Receivable; (c) Morgan Keegan \& Company, Inc. (MK), a brokerage and investment banking firm contractually affiliated with IBG, encouraged IBG to discontinue using the improper accounting method; (d) IBG's President Cordell made a misrepresentation to MK in 2007 when he stated that all of the questionable Accounts Receivable had been written off; (e) in 2008, MK became aware that IBG might change the accounting method; (f) MK never encouraged IBG managers to breach fiduciary duties to IBG; (g) MK did not owe IBG fiduciary duties, but even if it did, there is no evidence of a breach because MK encouraged discontinuance of the improper accounting practice; (h) some of the managers and directors of IBG were innocent, they did not participate in daily operations of the company, and they did not have control of the company; and (i) notwithstanding the fact they did not commit securities fraud, some of the "innocent" managers and directors failed to discharge their duties to IBG by advocating for the continued use of the improper accounting method. On appeal in 2021, the District Court affirmed the Bankruptcy Court, holding that: it did not make any legal errors; the Bankruptcy Trustee did not adequately prove damages caused by MK; and the Bankruptcy Trustee's claims were barred by the Doctrine of in Pari Delicto.
\end{abstract}

KEYWORDS: Auditor, Duty, Accounting, Practices, GAAP

\section{OBJECTIVES}

The objectives of this article are to: (a) review the literature of auditors' duty to ensure clients are using accounting practices in compliance with Generally Accepted Accounting Principles (GAAP); (b) analyze the case of Infinity Business Group, Inc. (IBG), focusing on its factual issues and legal issues; and (c) draw conclusions from the above.

\section{REVIEW OF THE LITERATURE}

Ketchland (2004) determined that auditors in small CPA firms are often willing to advocate for the use of clientpreferred accounting principles, and the risk that a client will be harmed by the auditor's aggressive behavior affects the likelihood of subordination of the auditor's judgment. Nerandzic (2012) explored the important role of the auditor's personality traits and morality in determination of whether he is likely to adhere to ethical principles of the auditing profession. Maclean (2014) investigated the critical role that auditors play in ensuring good governance and the adherence to accounting standards. In a study of 54 countries, Zengin Karaibrahimoglu (2016) investigated the impact of the perceived strength of auditing and reporting standards on the perceived ethical behaviors of business firms by highlighting the influence of national culture. Alzola (2017) argued that it was morally objectionable to hold auditors responsible for their clients' behavior not only on grounds of fairness but also on consequentialist grounds. In a study involving 25 countries, Vann (2018) explored the susceptibility of Big 4 auditing firms to engage in earnings management for their client firms, comparing principles-based and rules-based reporting regimes. Burke (2019) presented a case analysis of Lehman Brothers Holding, Inc. and stated that auditor Ernst \& Young committed professional malpractice when it issued an unqualified opinion with knowledge that the client had erroneously stated its liabilities; this illustrates that even Big 4 auditors may be prone to helping clients engage in earnings management. Voss (2019) studied the suitability and utilization of financial statements in managerial decision- 


\section{“Auditors' Duty to Ensure Clients are Using Accounting Practices in Compliance with Generally Accepted Accounting Principles: A Case Study of Infinity Business Group, Inc."}

making processes and evaluation of their reliability from the perspective of departmental managers and tax advisors. Zehri (2020) engaged in a meta-analysis of 75 studies and concluded that a firm's board of directors, audit committee and audit size are statistically significant in reducing the prevalence of earnings management in business firms. Yenny (2020) investigated the impact of the following characteristics of audit committees in determining whether a firm is likely to engage in earnings management: degree of expertise of audit committee in the industry, degree of expertise of audit committee in accounting and finance, number of meetings of the audit committee, and degree of independence of the audit committee.

The present article analyzes a recent legal case in which an auditor in a small CPA firm allowed the client to engage in earnings management by using an improper receivables valuation method, an act of securities fraud which led to the bankruptcy of the client. This article covers previously unexplored aspects of an auditor's facilitation of a client's earnings management scheme and it will enrich the literature.

\section{BACKGROUND OF THE CASE}

Infinity Business Group, Inc. (IBG) was incorporated in 2003. IBG was a payment processing company that specialized in the collection of not-sufficient-funds (NSF) checks. IBG would collect NSF checks and then obtain statemandated service charges upon the successful collection of the check. IBG offered two programs for collecting NSF checks: the Guaranteed Program and the Non-Guaranteed Program. Under the Guaranteed Program, IBG would become the owner of the bad check by paying its customer the face value of the check. Upon any collection, IBG would receive both the face value of the check and the service charge. Under the Non-Guaranteed Program, ownership of the NSF check remained with the customer. Upon collection of the bad check under the Non-Guaranteed Program, IBG would retain the service charge and pay the face value of the check to the customer (IBG case 2, pp. 2-3).

During the years of its operations, IBG was managed by a Board of Directors (Board) and several key managers, including the following:

- Bryon Sturgill: Chief Executive Officer (CEO) and Board member during 2003-2010. He reviewed and prepared the firm's financial statements during 2003-2006 and effectively served as Chief Financial Officer (CFO) during that period.

- Wade Cordell: President and Chairman of the Board during 2004-2009.

- Brad Cordell: Chief Operating Officer and Board member during 2004-2009.

- Haines Hargrett: a CPA who served as CFO during 2006-2010; he was not a member of the Board but frequently attended Board meetings.
- John Blevins: General Counsel and a member of the Board during 2004-2009.

- Thomas Handy: member of the Board during 20082010.

- Michael Potter: member of the Board during 20032007 and 2009-2010.

- Bill Van Hoeven: member of the Board during 2004-2010, manager of the firm's Processing Center during 2004-2006, and he subsequently served as Director of Information and Technology.

- Grafton \& Company, PLLC (Grafton): served as IBG's outside auditor during 2003-2009 and issued unqualified audit opinions on IBG's financial statements throughout this period (IBG case 2, pp. 3-5).

The Bankruptcy Court referred to Sturgill, Wade Cordell, Brad Cordell, Hargrett and Blevins as the "Management Defendants" because they were defendants in the adversary proceeding. The Bankruptcy Court referred to Handy, Potter and Van Hoeven as the "Non-Defendant Directors" because they were not named as defendants in the adversary proceeding (IBG case, p. 5).

In March, 2006, IBG entered into a contract with Morgan Keegan \& Company, Inc. (MK), a brokerage and investment banking firm. The 2006 contract provided that MK would serve as IBG's exclusive placement agent in exchange for a $6 \%$ commission on all gross proceeds raised on behalf of IBG from a private equity placement. After a potential investor withdrew its proposal, IBG and MK terminated that contract in October, 2006. MK discontinued its efforts to find institutional investors interested in investing in IBG after the 2006 contract ended but IBG's managers, employees and Board members continued to sell securities to investors directly. After the 2006 contract concluded, Keith Meyers (Meyers), a Vice President at MK who led the firm's efforts to find an institutional investor for IBG, continued to correspond with IBG's managers and personally invested \$25,000 in IBG in November, 2006. In April, 2008, IBG and MK entered into a second contract (for a 6-month term) in which MK agreed to be IBG's exclusive financial advisor with respect to possible debt financing in exchange for a contingent placement fee equal to $3 \%$ of the gross proceeds MK raised on IBG's behalf. The second contract concluded according to its terms in October, 2008 (IBG case 2, pp. 7-8).

In 2009, certain IBG shareholders alleged that Wade Cordell, Brad Cordell, and Blevins caused IBG's misappropriation of funds from the customer accounts and organized an effort to remove them. These three persons were removed from the Board and were terminated from their officer positions in August, 2009. 


\section{“Auditors' Duty to Ensure Clients are Using Accounting Practices in Compliance with Generally Accepted Accounting Principles: A Case Study of Infinity Business Group, Inc."}

In July, 2010, the Board removed CEO Sturgill and CFO Hargrett from their positions. IBG filed for bankruptcy under Chapter 7 of the Bankruptcy Code on September 1, 2010. Two years later, the Bankruptcy Trustee began an adversary proceeding on behalf of IBG against IBG's former managers, auditor Grafton, MK, and Meyers. Prior to trial, many of the individual defendants defaulted, confessed judgment, or entered into settlements with the Bankruptcy Trustee, leaving MK and Meyers (MK Defendants) as the remaining defendants at trial (IBG case 2, p. 8-9).

In 2018, the Bankruptcy Court began an 18-day bench trial on the Bankruptcy Trustee's claims against the MK Defendants. The Trustee asserted four causes of action against the MK Defendants: (a) securities fraud; (b) common law fraud; (c) breach of fiduciary duty; and (d) aiding and abetting a breach of fiduciary duty. The Trustee alleged that the MK Defendants were actively involved in creating and introducing the accounting practice used by IBG to recognize its Accounts Receivable with the intent of inflating the firm's revenues in order to overvalue the company and make it appear more profitable, the benefits of which would be realized by a higher commission for the MK Defendants upon any ultimate sale or merger of IBG. As an alternative theory of liability, the Trustee alleged that the MK Defendants were aware or should have been aware that the accounting method used to value the receivables was improper, and they failed to report this to the company; this failure was to the detriment of IBG because the Non-Defendant Directors remained unaware of the improper accounting method being used and did not have an opportunity to correct it (IBG case 2, pp. 911).

\section{LEGAL AND FACTUAL ISSUES}

A. Did the CEO use a non-GAAP accounting method when he prepared the company's financial statements in 2005?

Yes. The CEO, Sturgis, dramatically increased the amount of Accounts Receivable on IBG's books in 2005, from $\$ 148,000$ to $\$ 3.1$ million. He mistakenly believed that it was acceptable under GAAP to treat the service charge from NSF checks as an account receivable. Sturgis justified his action because the company's contract with its clients provided that IBG would be entitled to the service charge even if the client requested the check be returned. Sturgis was adamant that this practice was acceptable under GAAP; in fact, however, this practice is not allowed under GAAP (IBG case 1, pp. 29-30).

B. Did IBG's auditor, Grafton, incorrectly issue a clean, unqualified opinion of the firm's financial statements just prior to the firm's offering of stock in November, 2006?

Yes. Notwithstanding the firm's use of the non-GAAP method of receivables valuation, the auditor issued an unqualified, clean opinion. As a result, IBG was able to raise
\$2.6 million of additional capital during the 12 months following the erroneous unqualified opinion (IBG case 1, pp. 15-16, 67).

C. As a result of the auditor's issuance of the clean opinion, was this an unlawful misrepresentation under the Securities Exchange Act of 1934? If so, was the auditor punished for this violation?

Yes. Grafton pled guilty to one felony count of securities fraud because his unqualified opinion misrepresented IBG's financial position to the investors in the company's stock (IBG case 1, pp. 15-16).

D. If the company had used the "Effective Yield Method" to determine its accounts receivable, would that have been acceptable under GAAP?

Possibly. The Effective Yield Method may have been acceptable method. It provides that a debt collection firm can treat both fees and principal as a receivable, but only if the firm buys a pool of accounts for collection. Under that method, if the specific requirements are applicable, companies may be allowed to record their revenues based on expected collection rates of the accounts in the pool (IBG case 1, pp. 30-31).

E. When Regions Bank, one of IBG's lenders, asked IBG's $C F O$ for information regarding the composition of the $\$ 23$ million of receivables, did the CFO provide an acceptable answer?

No. The CFO tried to justify the continuation of the nonGAAP receivables valuation method that had originally been adopted by CEO Sturgis and later ratified by Grafton, the auditor. He said there were two categories of receivables: (a) "for guaranteed checks, we have already paid the merchant and everything we collect, we keep; and (b) "some are nonguaranteed, in which case the booked amount is only the portion of the fees that we expect to collect." However, he was candid enough to admit that "our current systems do not give us a very reliable method to determine exactly what is in the system, we do not know that there is approximately $\$ 23$ million in funds available to us if we collect all of them" (IBG case 1, pp. 65-66).

F. Did the MK Defendants cause IBG to implement or continue utilizing the fraudulent accounting practices that led to IBG's demise?

No. The Bankruptcy Court's finding that the firm's use of the improper accounting practices was perpetuated by both CEO Sturgill and the auditor, Grafton is supported by the evidence in this case. Sturgill first used the inflated receivables valuation procedure when he prepared the financial statements in 2005. Grafton facilitated the use of the inflated valuation by mistakenly issuing unqualified audit opinions on the financial statements during 2003-2008. The evidence also indicates that the MK Defendants did not have the authority to cause IBG to implement and utilize the inflated receivables valuation procedure. The contract between MK and IBG stated that MK's duties were to serve as a broker and 


\section{“Auditors' Duty to Ensure Clients are Using Accounting Practices in Compliance with Generally Accepted Accounting Principles: A Case Study of Infinity Business Group, Inc."}

ultimately an institutional investor to raise capital (IBG case 2, pp. 30-32).

G. Did IBG's President, Wade Cordell, lie to MK in 2007 by stating that IBG's questionable receivables had been written off earlier that year?

Yes. Wade Cordell lied to Meyers, an MK employee, because he wanted to raise more capital through MK. He presented a financial model of IBG's projected financial statements for the next four years (2008-2012). As a result of the misrepresentation, Meyers and several of his coworkers at MK invested at least $\$ 75,000$ more funds in IBG (IBG case 1, pp. 66-67).

H. In 2008, did MK become aware that IBG's CFO Hargrett was considering changing its receivables valuation method? Yes. In April, 2008, the CFO asked MK to gather information on revenue accounting from other companies because Infinity was considering changing to a more conservative receivables valuation method, notwithstanding the fact he believed the current method was GAAP-compliant (which it wasn't!). After MK provided the information, the CFO edited it and sent a document to MK explaining the new policy: "per the contract with the merchants, we are entitled to the fees arising from the collection efforts of those checks and per accounting requirements of matching revenue and expenses, was required to accrue the estimated revenue that will be received upon collection of these checks; again note that the accounts receivable balance only includes fees due to Infinity upon collection of the checks and does not include the face amount of the checks." In May, asked to respond to an inquiry of an institutional investor, the CFO indicated he would "write off all of the receivables this year and clean up the balance sheet" and that "after the write down, the accounts receivable balance will not be zero but will be less than $\$ 1$ million" Ultimately, Infinity wrote down $\$ 23$ million of its receivables as a one-time event, which was retroactively applied to January 1, 2009. This had a devastating effect on the company and it filed for bankruptcy on August 31, 2010. (IBG case 1, pp. 5-6, 73-75, 107).

I. At the time they became associated with IBG, did "red flags" or other indicia make the MK Defendants aware that the fraudulent accounting practices were in violation of $G A A P$ ?

No. MK entered into its first contract with IBG in 2006. The uncontradicted testimony of Meyers (a manager at MK) at trial indicated that he first learned that the receivables valuation practice was not compliant with GAAP on July 1 , 2008. On that date, Transactions Services, LLC (TS) issued a Financial Due Diligence Report on IBG. The TS Report concluded that IBG's "audited" financial statements were materially misstated, and should not be relied upon due to the material overstatement of revenue, net income and accounts receivable. The TS Report also noted that GAAP requires contingent fee revenue recognition to begin upon the collection of funds on behalf of customers (IBG case 2, pp. 38-39).

$J$. Did the MK Defendants conceal the fraudulent nature of the accounting practices from IBG's innocent Non-Defendant Directors, managers, investors and potential investors?

No. The MK Defendants did not collude to create the improper accounting practice to conceal IBG's true financial state, and they did not try to hide the accounting practice. The Bankruptcy Court stated: "Far from hiding its use, the improper receivables valuation practice was openly discussed by Meyers and other MK employees with IBG's management and the institutional investors it consulted. The evidence is uncontradicted that Meyers insisted on transparency when he discussed the matter with the institutional investors he brought to IBG" (IBG case 2, pp. 42-43).

$K$. Did the MK Defendants knowingly and substantially participate in or encourage the Management Defendants' breaches of fiduciary duties to IBG?

No. At trial, the Bankruptcy Trustee alleged that the MK Defendants aided and abetted the breach of the Management Defendants' fiduciary duties by looting IBG and by using IBG's capital for their own personal benefit. Aiding and abetting a breach of a fiduciary duty has four required elements: (a) a fiduciary relationship between two parties; (b) breach of the fiduciary relationship; (c) the defendant knowingly and substantially participated in or encouraged the breach of fiduciary duty; and (d) the plaintiff suffered damage as a result of the breach (Guifoyle case, p. 198). Whether the MK Defendants "knowingly and substantially participated in or encouraged that breach" is an issue of fact to be determined by the trial court. The trial court determined in this case that the MK Defendants did not engage in those wrongful acts. The MK Defendants: (a) did not know the receivables valuation method was fraudulent until July 1, 2008; and (b) did not know the Management Defendants were misappropriating company assets. Without this knowledge, the MK Defendants could not have participated in or encouraged the Management Defendants to breach their fiduciary duties to IBG (IBG case 2, pp. 45-47).

L. Did the MK Defendants Breach Their Fiduciary Duties and Duty to Disclose to IBG?

No. To establish a claim of Breach of Fiduciary Duty, a plaintiff must prove: (a) the existence of a fiduciary duty; (b) a breach of that duty; and (c) damages proximately resulting from the wrongful conduct of the defendant (RFT case, p. 173). In this case, the MK Defendants did not owe IBG a fiduciary duty. But even assuming arguendo that a fiduciary duty was owed, there could be no breach of the duty when considering Meyers and MK's efforts to advise IBG's management of issues concerning the non-GAAP receivables valuation practice, its openness to institutional investors about that accounting practice, and its support of $\mathrm{CFO}$ Hargrett's efforts to change the practice (IBG case 2, p. 50). 


\section{“Auditors' Duty to Ensure Clients are Using Accounting Practices in Compliance with Generally Accepted Accounting Principles: A Case Study of Infinity Business Group, Inc."}

M. Did IBG's innocent Non-Defendant Directors and managers participate in the daily operations and management of the company, and did they have the ability to control the company?

No. The Management Defendants controlled both the daily and long-term aspects of IBG's business. The innocent, NonDefendant Directors were not involved with IBG's business on a daily basis and were not in a position to control the company. Handy and Potter were solely affiliated with IBG as directors and held no managerial positions. The other director, Van Hoeven, also managed IBG's Processing Center and assisted in raising capital from individual investors, but he did not exert significant control over the company (IBG case 2, pp. 52-56).

N. Did IBG's innocent Non-Defendant Directors, managers and advisors fail to discharge their duties to the company, and were they aware of the fraudulent nature of the accounting practices and the misconduct of the MK Defendants and the Management Defendants?

Yes. At the January 2007 meeting of the Board of Directors, they discussed the receivables valuation method and the large increase in the accounts receivable account. CFO Hargrett advised them to change the valuation method, but they refused to do so. It was decided unanimously it was in the company's best interest to maintain the status quo and not to change the valuation method. Also, the explanatory note to IBG's audited financial statements during 2004-2008 indicates that IBG had actual knowledge of the receivables valuation issue. The note stated that the company's accounts receivable balance includes state-mandated fees and that IBG is "actively collecting that amount" (IBG case 2, pp. 57-58).

O. Did the Bankruptcy Court err as a matter of law by holding that the MK Defendants did not owe IBG a fiduciary duty, a duty of due diligence, or a duty to disclose all material facts?

No. The relationship between MK and IBG was defined by the two contracts they entered into. In those two contracts, there is no mention of MK agreeing to serve IBG in those expanded capacities. Instead, the contracts stated that MK could rely on the financial information it received from IBG without having to independently verify its accuracy. Also, the contracts did not give MK any control over IBG's operations, its accounting policies, its financial statements, or its assets (IBG case 2, pp. 59-61).

\section{P. Did the Bankruptcy Court err when it concluded that the} Bankruptcy Trustee's claims were barred by the Doctrine of In Pari Delicto?

No. The Doctrine of In Pari Delicto is an affirmative defense that precludes a plaintiff who participated in the same wrongdoing as the defendant from recovering damages from that wrongdoing (Derivium case, p. 367). The Bankruptcy Court concluded that in pari delicto precluded each of the Bankruptcy Trustee's claims because IBG would equally be a wrongful actor in regards to the alleged impropriety and the consequences resulting from the improper receivables valuation practice. The Bankruptcy Court's ruling on this issue was held to be not clearly erroneous and was affirmed by the District Court in this appeal (IBG case 2, pp. 73-99).

$Q$. Did the Bankruptcy Court's finding that the Trustee did not adequately prove damages caused by the MK Defendants misrepresent the evidence and misapply the law?

No. The Bankruptcy Trustee presented only one theory of damages, i.e., that damages are equal to IBG's net operating losses. The Trustee alleged that IBG's net operating losses were the foreseeable and proximate result of the MK Defendants' conduct, but this is not accurate. The operating losses are too tenuously connected to MK's actions to meet the foreseeability requirement of proximate causation, and there were nine (9) legally significant intervening causes of IBG's operating losses. The evidence indicates that IBG's operating losses would have occurred with or without the presence of the MK Defendants. The MK Defendants did not cause IBG to implement the improper receivables valuation method; in fact, Meyers encouraged disclosure of the improper method and advised IBG to change it (IBG case 2, pp. 99-101).

$R$. What was the final outcome in this case?

On March 31, 2021, the District Court affirmed the order and judgment issued by the Bankruptcy Court on October 15, 2019 and dismissed the Bankruptcy Trustee's appeal (IBG case 2, p. 1).

\section{CONCLUSIONS}

A. Infinity Business Group, Inc. (IBG) booked all of its collection fees as Accounts Receivable even before the NotSufficient-Funds (NSF) checks had been collected. This accounting method was not in compliance with Generally Accepted Accounting Principles (GAAP).

B. IBG's auditor should not have issued unqualified opinions on IBG's financial statements during 2003-2008 because of the use of the non-GAAP method.

$\mathrm{C}$. The auditor's issuance of the unqualified opinions during 2003-2008 was an unlawful misrepresentation in violation of the U.S. Securities Exchange Act of 1934. Accordingly, the auditor pled guilty to one (1) felony count of securities fraud.

D. The Effective Yield Method of accounting for service fees may have been acceptable if IBG had purchased a pool of accounts for collection.

E. IBG's CFO was not completely honest when he responded to an inquiry from one of its lenders about the composition of IBG's Accounts Receivable. He tried to justify the use of a non-GAAP accounting method.

F. Morgan Keegan \& Company, Inc. (MK) is a brokerage and investment banking firm that entered into two (2) contracts with IBG. MK had nothing to do with IBG's decision to begin using, or to continue using, the non-GAAP accounting method. The improper method was implemented by Sturgis, the CEO, and was later ratified by the auditor 


\section{“Auditors' Duty to Ensure Clients are Using Accounting Practices in Compliance with Generally Accepted Accounting Principles: A Case Study of Infinity Business Group, Inc."}

when he issued unqualified opinions on the financial statements.

G. IBG's President Cordell made a misrepresentation to MK in 2007 when he stated that all of the questionable Accounts Receivable had been written off during that year.

H. In 2008, MK became aware that IBG's CFO, Hargrett, was considering changing the accounting method used for collection fees while simultaneously contending the original method was acceptable. Eventually, Hargrett write off \$23 million of the Accounts Receivable. This had a devastating effect on IBG and it declared Chapter 7 (liquidation) bankruptcy on August 31, 2010.

I. MK entered into a contract with IBG in 2006. At that time, MK was unaware that the Accounts Receivable valuation was overstated or that the accounting method was in violation of GAAP.

J. MK never concealed the fact that IBG used an improper accounting method. In fact, MK openly discussed that method with IBG's managers and with institutional investors it consulted with.

K. MK never knowingly or substantially participated in or encouraged the IBG management to breach their fiduciary duties to IBG.

L. MK did not owe IBG any fiduciary duties, but even assuming it did, there is no evidence of a breach because MK openly discussed IBG's improper receivables valuation practice and encouraged it to be changed.

M. Some of the managers and directors of IBG were innocent, they did not participate in the day-to-day operations of the company, and they did not have the ability to control the company.

N. Notwithstanding the fact they were not responsible for the securities fraud, some of the "innocent" managers and directors failed to discharge their duties to the company; they were aware that the receivables accounting method was improper, yet concluded that it was in the best interest of the company to continue using the improper method.

O. The Bankruptcy Court did not err as a matter of law when it held that MK did not owe IBG any fiduciary duties.

P. The Bankruptcy Court did not err as a matter of law when it held that the Bankruptcy Trustee's claims were barred by the Doctrine of In Pari Delicto.

Q. The Bankruptcy Court did not misrepresent the evidence and misapply the law when it held that the Bankruptcy Trustee did not adequately prove the damages caused by MK.

R. The District Court, serving as the appellate court in this case, affirmed the judgment of the Bankruptcy Court on March 31, 2021.

\section{REFERENCES}

1. Alzola, M. (2017). Beware of the Watchdog: Rethinking the Normative Justification of Gatekeeper Liability. Journal of Business Ethics, 140:4, 705-721.
2. Anderson v. Meyers (in re Infinity Bus. Grp., Inc.), 612 B.R. 76 (Bankruptcy Court for the District of South Carolina, October 15, 2019). [IBG case 1]

3. Anderson v. Cordell (in re Infinity Bus. Grp., Inc.), 2021 U.S. Dist. LEXIS 65185 (U.S. District Court for the District of South Carolina, Columbia Division, March 31, 2021). [IBG case 2]

4. Burke, J.J. (2019). Deconstructing the Use of REPO 105 and REPO 108 Transactions Under SFAS 140: the Case of Lehman Brothers Holding, Inc. and the Liability of Ernst \& Young. Academicus, 19, 12.

5. Guifoyle v. Olde Monmouth Stock Transfer Co., Inc., 335 P.3d 190 (Nevada 2014). [Guifoyle case]

6. In re Derivium Capital LLC, 716 F.3d 355 (4 $^{\text {th }}$ Circuit 2013). [Derivium case]

7. Maclean, S. (2014). Examining Auditing as an Essential Element of Financial Management and Good Governance in Local Government. Africa's Public Service Delivery and Performance Review, 2:2.

8. Nerandzic, B., Perovic, V., Zivkov, E. \& Pascan, S. Personality and Moral Character Traits and Acknowledging the Principles of Management Ethics, Auditing and Accounting Ethics. (2012). Ekonomska Istrazivanja, Supp. 1, 25, 288-312.

9. RFT Mgmt. Co., L.L.C. v. Tinsley \& Adams L.L.P., 132 S.E.2d 166 (South Carolina 2012). [RFT case]

10. Shafer, W.E., Ketchand, A.A. \& Morris, R.E. (2004). Auditors' Willingness to Advocate ClientPreferred Accounting Principles. Journal of Business Ethics, 52:3, 213-227.

11. Vann, C.E. \& Presley, T. (2018). Big 4 Auditors, Corporate Governance, and Earnings Management under Principles- and Rules-Based Reporting Regimes: Cross-Country Empirical Evidence. Journal of Managerial Issues, 30:3, 279.

12. Voss, G. (2019). Information and Strategic Aspects of Financial Statements in the Assessment of their Users. Folia Oeconomica Stetinensia, 19:2, 176-187.

13. Yenny, D.H. \& Ewing, Y.I. (2020). The Effect of Audit Committee Characteristics on Earnings Management and its Impact on Firm Value. International Journal of Commerce and Finance, 6:2, 104-116.

14. Zehri, F. \& Zgarni, I. (2020). Internal and External Corporate Governance Mechanisms and Earnings Management: an International Perspective. Accounting and Management Information Systems, 19:1, 33-64.

15. Zengin Karaibrahimoglu, Y. \& Guneri Cangarli, B. (2016). Do Auditing and Reporting Standards Affect Firms' Ethical Behaviours? The Moderating Role of National Culture. Journal of Business Ethics, 139:1, 55-75. 